\title{
Parental Influence on Students' Career Choice and its Effect on Their Academic Performance. A Case of Schools in Rulindo District
}

\author{
Mbonimana Gamariel ${ }^{1}$, Byishimo Blaise ${ }^{2}$ \\ ${ }^{1}$ Senior Lecturer at University of Kigali, Rwanda \\ ${ }^{2}$ Student at University of Kigali, Rwanda \\ *Corresponding Author: Mbonimana Gamariel
}

\section{Abstract}

The goal of this research was to determine the degree to which parental influences impact job choice and performance among advanced level students in Rulindo District, Rwanda. Additionally, the research intended to identify the interaction between children and parents in terms of profession choice and the value of collaboration. The research population consisted of all 2000 pupils enrolled in Rulindo's three elementary schools. The research surveyed a total of 108 pupils, and they all answered. Providing a response rate of $100 \%$. Purposive sampling was employed to sample three schools in Rulindo District, while simple random sampling was utilized to sample the pupils. Questionnaires were employed to gather data. The data were analyzed using the Statistical Package for Social Sciences (SPSS) program. The data were analyzed using descriptive statistics such as frequencies and percentages. Tables and graphs were used to show the findings. The study's findings indicated that parental variables had an effect on students' profession choices in Rulindo. These variables included the parents' greatest level of education, their employment, their beliefs and expectations, and their parentchild connections. The research advised that parents and children discuss higher level courses before to enrolling in them, emphasizing on the learner's strengths and preferences in order to minimize potential difficulties. This enables students to make informed job choices based on their educational attainment and professional goals.

Keywords: Parental, Influence, Career, Students \& Performance

\section{Introduction}

Parents are often said to be a child's first and finest instructors. The research corroborates this assumption, demonstrating that parents' effect on their children's education starts as early as preschool. Parental influence extends beyond the parent-child bond to parental qualities, education, and money, as well as parental interactions with their children and their children's schools (Zhao et al., 2017; Lu, 2012). Parental perspective is critical in many aspects of a child's life, including academic, professional, and personal. Parental guidance is critical in a child's life and has a substantial impact on two important life events: marriage and career choice (Hasib et al., 2021). The impact of parents on their children's professional choices is widely recognized, regardless of gender or race.

A career may be described as the succession of roles performed by an individual over the course of a lifetime. It is a person's motivation for education, job, and other aspects of life. Another meaning of career development is the progression and activities made by an individual during the course of their lives, particularly those linked to their employment, in order to 
obtain top management positions. Career choice is critical in shaping an individual's personality and life ideas, not because it determines an individual's income, but because it forms an individual's personality and life conceptions (Billett, 2006; Hasib et al., 2021). Thus, career choice is a commitment to a lifetime of labor, growing in one's vocation. In a nutshell, everything a person undertakes prepares him or her for a future job.

Career choice is a difficult decision to make, all the more so when a person's life is at stake. Career choice is the sum total of experiences through which an individual learns about and prepares to participate in work as a way of life (Austin, 2002).

Profession is a process that unfolds throughout one's life and encompasses the family, school, and community (Hipp et al., 2008). Every human person must do some function in order to contribute to the country's progress.

At several schools, most notably in the Rulindo District, you will see that some students have been pursuing combinations of subjects that are not their first choice and do not align with their dreams. This seems to be because their parents have persuaded them to follow such combinations. These decisions result in failures, stress, and poor performance. Finally, youngsters become victims of their inability to do well in class.

They forfeit even opportunities to perform what they want, so that the task for which they have been picked provides them no pleasure. However, little studies have been conducted to date on the issue of parental impact on children's choices and educational influences in a variety of nations. While a recent research examined the impact of parental influence on kids' job choices and academic achievement. By highlighting the detrimental consequences on educational growth, particularly in the Rulindo District's schools.

\section{Statement of the Problem}

Parents have a significant effect on their children's job development and professional choices. Parents want their children to be happy and successful in life, and one aspect that contributes to happiness and success is profession selection. Additionally, research suggests that when adolescents feel supported and loved by their parents, they develop a greater confidence in their own capacity to do job study and pick an intriguing and exciting vocation. This is important because research indicates that teenagers who feel competent in terms of profession choice make more satisfied job choices later in life (Hirschi, 2009; Clausen, 1991).

Though parents have a critical influence in their children's job choices, parents might have a detrimental impact on their children's choice of Advanced level courses in Rwanda's present education system. This sometimes happens when a youngster chooses a professional path based on his or her ambitions and abilities, such as Maths-Economics and Geography (MEG), but is persuaded by parents to pursue another path, such as Maths-Chemistry and Biology (MCB) or Physics-Chemistry and Mathematics (PCM). They are often persuaded to choose alternatives or combinations within the Rwandan educational system that are contrary to their aspirations and interests by their parents, who want them to pursue careers as engineers, doctors, or other professionals. Regardless of whether kids are capable of doing better or not.

As a result, some students in Advanced levels, which are equivalent to senior four, five, and six, face numerous challenges throughout their education, including failures, stress, poor performance in certain subjects, a lack of interest and motivation as a result of having their first choice (career) rejected and being forced to pursue other combinations. 
Parents should be warned against putting their own objectives on their children or seeing their child's success as a mirror of their own (Alderson, 2007). While parents should demonstrate real interest in and support for their children's job choices, they must also enable youngsters to find their true selves on their own.

Clearly, the entire study's objective was to ascertain parental influence on students' career choices and its effect on academic performance, as well as to determine whether parents' influence and guidance in the area of career choice and vocational development provide students with support and encouragement to explore the numerous options available to them in order to find the best career that fits their unique combination of skills and interests.

\section{Research Objectives}

This dissertation has several objectives to put across but the main ones are presented as follows: (1) To find out the parental influence on students' career choice and its effect on their academic performance in Rulindo secondary schools; (2) To assess the challenges that students face in their daily learning activities due to the rejection of their wills and preferences; (3) To evaluate how parents can listen to their children in terms of career choices; (4) To investigate how important it is giving children the freedom to choose plays a significant role in their academic success; (5) To formulate suggestions on what should be done to prevent the challenges that students face in career choices.

\section{Theoretical Literature}

Parents with varying demographic and psychographic features have varying expectations for their children's schooling, which ultimately influences their children's job choices. The prevailing perception of parents towards their children's education is that it should be used to get more respect and money rather than to effect good change in society.

\section{Parental Influence}

Parental influence is described as any view, attitude, or action on the part of the parent (other than direct tutoring) that moulds or molds the child's reading attitudes in some way. Involvement is defined as any direct tutorial assistance a youngster gets in order to improve his or her reading ability.

A career is distinguished from a job in the following ways: A job is something you perform only for the purpose of earning money; a career is a linked sequence of work chances. While a job has little bearing on your future work life, a career gives experience and education that will power your future.

\section{Career Choices and Development Theories}

Professional choice is the process of determining an appropriate career path. A professional decision is critical since it impacts your performance in subsequent phases of life (Murphy et al., 2018). Individual growth, organizational growth, economic growth, and waste reduction are all critical components of job choice.

\section{The Following Are Some Ideas On Career Growth And Choice}

(1) Holland's Theory of Vocational Personalities in the Work Environment, (2). Work Adjustment Theory (TWA), and (3) Structuralism theory heorem of Social Cognitive Careers.

No one career development theory was proven to be comprehensive. The basic tenet of all theories was career advice as a collection of many and disparate thoughts. 


\section{Holland's Theory of Vocational Personalities in Work Environment}

Holland's career choice theory was one of the most thoroughly explored hypotheses, arguing that congruence between one's fundamental personality type and chosen job was a critical component in achieving professional success. His hypothesis was often utilized as the foundation for career counseling sessions by experts. According to this theory, the majority of individuals fall into one of six fundamental personality types: Realistic, Investigative, Artistic, Social, Enterprising, or Conventional. These are often referred to as Holland Codes or RIASEC. Theorists argued that individuals who worked in an environment that matched their personality attribute were more prosperous and satisfied.

\section{Factors Influencing Career Choices}

When an individual considers his or her future vocation and job choice, various considerations come into play. The most critical factors are the job description, the necessary skills and education, the compensation, and the career prospect.

However, there are other other significant elements that might impact a person's profession decision. The researcher discusses some of these elements in this study. It is important to consider them before making a choice on one's future job. Everyone has to make the appropriate option, consider the advantages and disadvantages, and this will assist him or her in finding the ideal vocation.

\section{Critical Review and Research Gap Identification}

Numerous studies undertaken by various scholars examined the effects of parents on their children's job growth and choice. Keller asserts that parents have a significant effect on their children's professional development and decision-making. Parents want their children to be happy and successful in life, and one aspect that contributes to happiness and success is profession selection.

Additionally, research suggests that when adolescents feel supported and loved by their parents, they develop a greater confidence in their own capacity to do job study and pick an intriguing and exciting vocation. This is important because research indicates that teenagers who feel competent in terms of profession choice make more satisfied job choices later in life (Hirschi, 2009).

Parents are often said to be a child's first and finest instructors. The research corroborates this assumption, demonstrating that parents' effect on their children's education starts as early as preschool. Parental influence extends beyond the parent-child bond to parental qualities, education, and money, as well as parental interactions with their children and their children's schools.

According to academics Kathleen Cotton and Karen Reed Wikelund, "parental participation in children's learning is favorably associated to achievement" for all kinds and ages of students, and the greater the intensity of this participation, the more beneficial the benefits.

Career is defined by Redman and Wilkinson (2001) as the application of a person's cognition and capacities, offering mastery over a profession, timely job knowledge, and a foundation for creating and improving business networks. Individuals undertake career planning in order to accomplish professional goals by staying informed about impending possibilities, their outcomes, and their timely reviews. It is regarded a starting point in the phases of professional selections but is still critical. Individuals want careers that may give a solid foundation for a 
better level of life (Cavus, Geri and Turgunbayeva; 2015). Individual career planning is a strategy for how an individual will advance in his field. On an organizational level, it discusses promotional issues in addition to the personal development quadrant. Thus, career planning is the process by which a person or an organization assists a person in pursuing his or her developmental objectives in accordance with his or her area of competence, competencies, and goals (Bayraktarolu, 2011). Career choosing is a critical component of an individual's life (Alberts et al. 2003). Numerous difficulties confront students throughout their career decision process (Olamide and Olawaiye, 2013). A poor job choice might have life-long implications (Mashige and Oduntan, 2011). By underperforming, such individuals become a source of inefficiency not just for themselves and their business, but also for the economy as a whole. (2008) (Issa and Nwalo). According to many study results, parental effect on a child's job choice and growth is under-researched in Rwanda. In Rwanda, studies on profession choices focused mostly on the determinants and relevance of parents in profession choices for general elements of life. The purpose of this research is to ascertain the effect of parents on their children's career choices, namely in education, among students attending schools in Rwanda's Rulindo District.

\section{Methods}

\section{Research Design}

As stated before, the purpose of this study was to investigate parental impact on students' job choices and its impact on academic achievement in Rulindo District. The researcher accomplished this by collecting both primary and secondary data. Primary data were collected through questionnaires, interviews, and observations completed by respondents from chosen schools in Rulindo District, while secondary data were gathered from printed sources such as books, journals, reports, archives, and also electronic sites linked to the issue.

\section{Target Population And Sampling Procedures}

The term "population" refers to a group of individuals or any other collection of objects considered for the purpose of study. According to Grinnell and Williams (1990:136), a population is defined as the whole of individuals or things included in a research. The population consists of Advanced level students (Senior four, Senior five, and Senior six) from chosen schools, as well as some parents. Carl and Roger (1991) said that a population research is concerned with the overall group of individuals from whom the forms are derived.

\section{Sampling Procedures}

A sample is a subset of the population that has been purposefully chosen for the aim of examining the target population's features (Kainada, 2008). We worked with a sample size of 108 pupils, including parents, in this example of Rulindo District.

\section{Results and Discussion}

This study examined the impact of parental influence on students' profession choices and academic performance in a case study of schools in Rwanda's Rulindo District. Chapter 1 introduced the study's context, which includes global, regional, and local views on parental influence and its impact on students' career choices. The chapter addressed the research issue statement, emphasizing the goal, goals, and research questions that guided the overall body of study. Additionally, the study's scope and importance were determined. 
Chapter 2 established a correlation between parental influence on a kid's job and the impact on the youngster. The theoretical review, empirical review, and conceptual framework all aided in establishing this connection. The theoretical examination uncovered flaws, gaps, urgent relevance, and contributions. The empirical review included scientific results about the relationship between parents' professional choices and their children's academic success. The conceptual framework highlighted the characteristics of the two variables in the study, and the analysis of their connection contributed in achieving the study's stated research aims and offered evidence that professional barriers may be overcome.

Chapter 3 discussed the study's approach. The methodology included the study's design, population, sampling techniques and equipment, as well as data processing and analysis. This chapter also discussed limitations and ethical issues. The research used the field survey technique to examine data obtained from a 2000-person study population and a 108respondent sample size estimated using the Bouchard formula. As a result, 108 legitimate responders were obtained. As a result, the study's findings were compiled using both respondents' perspectives and data from key informants. This methodology made a significant contribution to the research's validity.

Chapter 4 contains the presentation of the data analysis and interpretation. Secondary schools in Rulindo District served as a baseline for empirical evaluation. Respondents' perspectives were studied, as were the data supplied by significant respondents, and conclusions drawn on parental influence on students' careers and its impact on academic success. In Chapter 4, the respondents' perspectives align with the study questions and aims. While addressing observations, solutions were offered to reduce difficulties. This chapter provided the researcher with further insight into the impact of parental influence on students' careers and academic achievement. As a result, chapter 5 would summarize the study's results, conclusions, and recommendations, as illustrated below.

\section{Conlusion}

The initial purpose was to determine the effect of parental influence on profession choices. The researcher posed questions and the following findings were obtained: Respondents' perspectives on how parents affect their children's choice of combination: Not sure replies accounted for 2.8 percent, disputed answers accounted for 4.6 percent, strongly disagreed answers accounted for 4.6 percent, and strongly agree answers accounted for 26.9 percent. Those who agreed with the allegation accounted for 61.1 percent. Only $61 \%$ agreed that their parents affect their choices. The second description of the study goal, which was to determine if students suffer difficulties when forced to pick a combination different from their first selection. The responses indicate that both strongly agree and agree cover $70 \%$ of the results from the questionnaire given to learners, indicating that once parents influence students to choose a combination other than their first choice, many students perform poorly in those combinations, despite the fact that some students cope and manage to keep up with them and earn good grades. The third purpose was to determine the extent to which allowing children to make their own choices contributes to their academic achievement. Participants were asked a series of questions and agreed at an 87 percent rate that their views must be heard. Finally, several ideas were made on how profession choices may be improved.

\section{Recommendations}

It has been established that parents have an influence on the career choice of students' combinations of studies. In light of this, it is recommended to do the following: (1) Parents' 
roles are important in education but they need to strongly hear the children upon their choices; (2) Parents should not force students to pursue careers similar to their own against their will. This is because majority of the students indicated they are affected by this negatively; (3) The ministry of education should strengthen the career counselling services in schools; (4) Schools should also develop the career counselling programs that enables learners to grow with career decisions before the completion of ordinary level; (5) Parents should realize that their values and expectations influence the career choice to a great extent. In this respect it is recommended that parents should deliberately communicate their expectations to their children without being overly persuasive; (6)Finally students should also play a big role in showing what they are able to do and why they want to pursue this or that combination.

\section{References}

Alderson, P. (2007). Competent children? Minors' consent to health care treatment and research. Social science \& medicine, 65(11), 2272-2283.

Austin, A. E. (2002). Preparing the next generation of faculty: Graduate school as socialization to the academic career. The journal of higher education, 73(1), 94-122.

Billett, S. (2006). Relational interdependence between social and individual agency in work and working life. Mind, Culture, and Activity, 13(1), 53-69.

Clausen, J. S. (1991). Adolescent competence and the shaping of the life course. American journal of sociology, 96(4), 805-842.

Hasib, M., Yassi, A. H., \& Nasmilah, N. (2021). Synchronizing Students Learning Styles in Promoting Learners' Grammatical Knowledge; a Cultural Dimensions Study. International Journal of Multicultural and Multireligious Understanding, 8(2), 264-272.

Hipp, K. K., Huffman, J. B., Pankake, A. M., \& Olivier, D. F. (2008). Sustaining professional learning communities: Case studies. Journal of educational change, 9(2), 173-195.

Hirschi, A. (2009). Career adaptability development in adolescence: Multiple predictors and effect on sense of power and life satisfaction. Journal of Vocational Behavior, 74(2), 145-155.

Hirschi, A. (2009). Career adaptability development in adolescence: Multiple predictors and effect on sense of power and life satisfaction. Journal of Vocational Behavior, 74(2), 145-155.

Holland, J. L. (1973). Making Vocational Choices: A Theory of Careers. Englewood Cliffs, NJ: Prentice Hall.

Lu, Y. (2012). Education of children left behind in rural China. Journal of Marriage and Family, 74(2), 328-341.

Murphy, K., Torres, E., Ingram, W., \& Hutchinson, J. (2018). A review of high performance work practices (HPWPS) literature and recommendations for future research in the hospitality industry. International Journal of Contemporary Hospitality Management.

Zhao, C., Wang, F., Li, L., Zhou, X., \& Hesketh, T. (2017). Long-term impacts of parental migration on Chinese children's psychosocial well-being: mitigating and exacerbating factors. Social psychiatry and psychiatric epidemiology, 52(6), 669-677. 